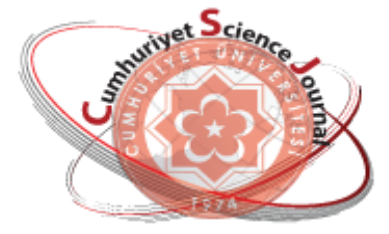

e-ISSN: 2587-246X

ISSN: $2587-2680$

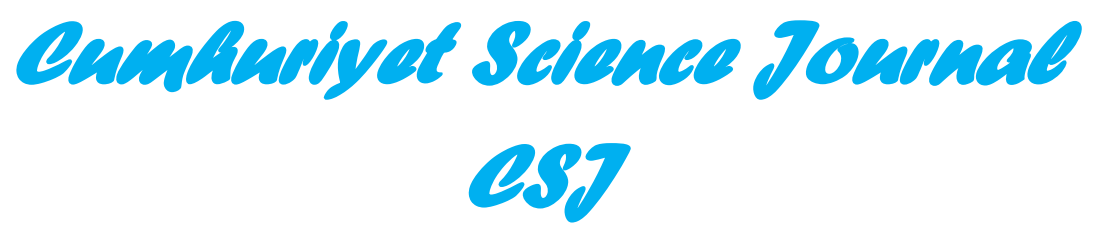

Cumhuriyet Sci. J., Vol.39-2(2018) 357-365

\title{
Investigation of Antitumor and Antibacterial Properties of Some New Thiophene-2,5-Dicarboxylic Acid bis-aryl (alkyl) amide Compounds
}

\author{
Pelin KOPARIR ${ }^{*}$, Akif Evren PARLAK \\ ${ }^{1}$ Institute of Forensics, Department of Chemistry, Malatya, TURKEY \\ ${ }^{2}$ Firat University, Vocational School of Keban, Elazig, TURKEY
}

Received: 03.04.2017; Accepted: 22.05.2018

http://dx.doi.org/10.17776/csj.412145

\begin{abstract}
Thiophene-derived compounds are of interest in chemistry, biology and pharmacology because of their various pharmacological activities This study aims to investigate the antitumor and antibacterial activity of thiophene-2,5-dicarboxylic acid bis-aryl (alkyl) amide compounds. In this study, the properties of antibacterial and antitumor were determined in vitro media, for all compounds.
\end{abstract}

As a result, cell viability experiments show that some of this compounds have effective in vitro antitumor activity. In addition, it has also been found that some compounds have an effective antibacterial activity.

Keywords: Thiophene-derived compounds, antitumor activity, antibacterial activity, antimicrobial activities, cancer.

\section{Bazı Yeni Tiyofen-2,5 Dikarboksilik Asit bis-aril (alkil) amid Bileşiklerinin Antitümör ve Antibakteriyel Özelliklerinin İncelenmesi}

Özet: Tiyofen türevli bileşikler, çeşitli farmakolojik aktiviteleri nedeniyle kimya, biyoloji ve farmakolojide ilgi uyandırır. Bu çalışma, tiyofen-2,5-dikarboksilik asit bis-aril (alkil) amid bileşiklerinin antitümör ve antibakteriyel aktivitesini araştırmayı amaçlamaktadır. Bu çalışmada, tüm bileşikler için antibakteriyel ve antitümör özellikleri in vitro ortamda belirlenmiştir.

Sonuç olarak, hücre canlılığı deneyleri, bu bileşiklerin bazılarının in vitro anti-tümör aktivitesine sahip olduğunu göstermektedir. Ayrıca, bazı bileşiklerin etkili bir antibakteriyel aktiviteye sahip olduğu da bulunmuştur.

Anahtar Kelimeler: 1-3-4 tiadiazol, antioksidan aktivite, radikal süpürücü aktivite, biyolojik aktiviteler.

\section{INTRODUCTION}

Cancer is a complex disease. According to molecular and cell biology, cancer is an abnormal gene expression disease [1]. Cancer usually refers to abnormal cell proliferation. Tumor is also known as neoplasm which means cancer formation and regeneration. No chemical compound has yet been found to completely treat any form of cancer today [2]. The goal in cancer treatment is to develop compounds with increased selective (selective) toxicity to provide more effective treatment and with reduced or no undesirable side effects that occur during and after the treatment. For this reason, investigation of new alternative agents is needed in cancer treatment and prevention. Investigation of new drug substances will provide new approaches for the development of potential cancer drugs in cancer treatment.

In this study, we planned to investigate the potential antitumor activities of newly

\footnotetext{
* Corresponding author. Email address: akifevren@firat.edu.tr

http://dergipark.gov.tr/csj C2016 Faculty of Science, Cumhuriyet University
} 
synthesized compounds against rodent leukemia. We have also examined the antibacterial properties of these compounds.

Thiophene-derived compounds are of interest in chemistry, biology and pharmacology due to their various pharmacological activities. It is stated that the structure and conformation of the molecule greatly alter the biological activities of such compounds [3].

In recent years, new syntheses have been put forward in order to reduce or terminate the effects of viruses and bacteria. In such studies, it has been shown that compounds containing the thiophene ring system possess a wide variety of biological activities viz. antiinflammatory [4,5], antidepressant, analgesic, anticonvulsant and antimicrobial etc. [6]. It is also known that some drugs with thiophene play an active role in the treatment of septicemia [7-10].
In particular, antiviral, antineoplastic, antiproliferative, antitumor, antifungal, antiparasitic and antiameboic effects of thiophene-containing compounds are investigated and experimental results are revealed [11-26].

In this study, the antitumor and antimicrobial activities of newly synthesized thiophene-2,5dicarboxylic acid bis-aryl (alkyl) amide compounds were investigated in vitro .

\section{MATERIAL and METHODS}

\subsection{Compounds Used in Trials}

Thiophene-2,5-Dicarboxylic Acid Bis-Aryl (Alkyl) Amide compounds used in this study were firstly synthesized by Prof. Dr. Metin Koparır et al. [27] in the Chemistry Laboratory of the Department of Chemistry, Faculty of Arts and Science, Firat University [figure 1]. The names of the compounds synthesized by 3 a-e codes are given in Table 1.

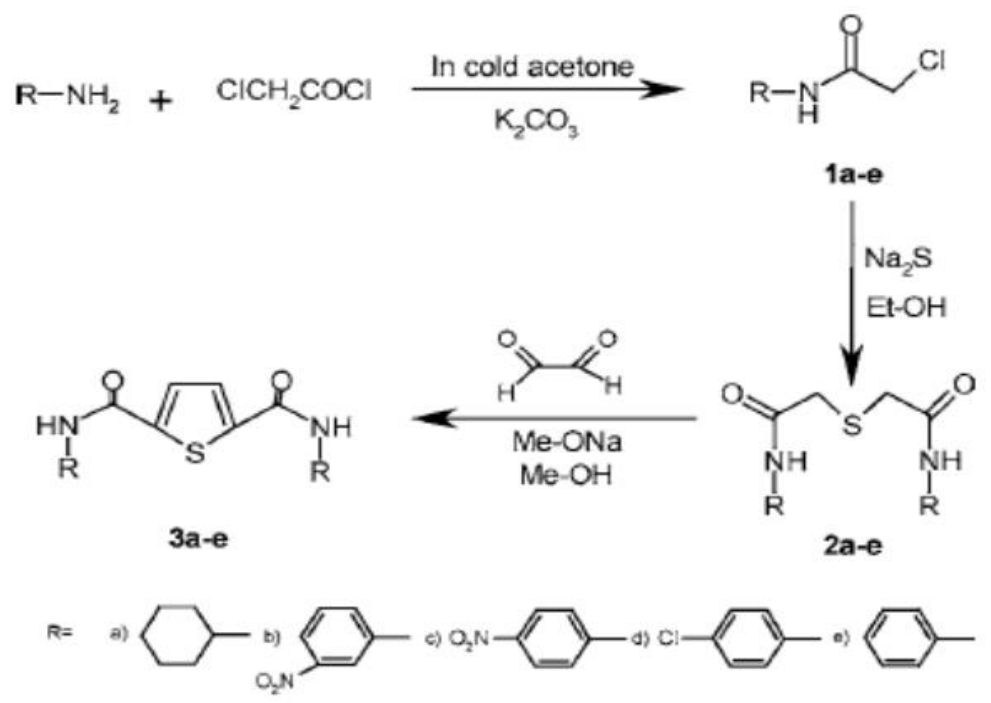

Figure 1. Synthesis scheme of test compounds [27].

Table 1. Nomenclature of compounds.

\begin{tabular}{ll}
\hline 3a & Thiophene-2,5-dicarboxylic acid bis(cyclohexylamide) \\
3b & Thiophene-2,5-dicarboxylic acid bis[(3-nitrophenyl)amide] \\
3c & Thiophene-2,5-dicarboxylic acid bis[(4-nitrophenyl)amide] \\
3d & Thiophene-2,5-dicarboxylic acid bis[(4-chlorophenyl)amide] \\
3e & Thiophene-2,5-dicarboxylic acid bis(phenylamide) \\
\hline
\end{tabular}




\subsection{Investigation of antitumor activity}

L 1210 cell culture (rodent leukemia cell) was used to determine antitumor activity. Frozen L 1210 rodent leukemia cells from the cell culture bank (Sigma, USA) were dissolved in room temperature and transferred into a $75 \mathrm{ml}$ flask. $\mathrm{DC}_{5}(25 \mathrm{ml})$, previously prepared, was added to the flask and flasks were placed in a Nuaire brand, $5 \% \mathrm{CO}_{2}$ medium incubator (Playmouth, MN, USA). The cells were examined daily using an inverted microscope of the Soif brand (Soif Optical Inc., China), and at the end of the third day, the $\mathrm{DC}_{5}$ in the flask was withdrawn and replaced with freshly prepared $\mathrm{DC}_{5}$. This process was repeated continuously every three days.

The cells, which continued to increase in number, began to form layers on top of each other by completely covering the base of the flask. At the end of the 15th day, the medium in the flask was withdrawn and replaced with $3 \mathrm{ml}$ of trypsin. The flasks were shaken slightly for 2-3 minutes to allow the cells to separate from the adhered surface. After all cells were separated from the surface of the flask, $12 \mathrm{~mL}$ of $\mathrm{DC}_{5}$ was added to the flasks and trituration (pipetting a cell suspension up and down) was carefully carried out to homogeneously spread the cells in the solution.

Cells were counted using a hemocytometer. A cell suspension was added to each flask $\left(1 \times 10^{5}\right.$ cells/flask), cells were supplemented with $\mathrm{DC}_{5}$ (total volume $25 \mathrm{ml}$ ), and all flasks were placed in the incubator. The cultivation, feeding and experiments of the cells were carried out in a sterile Class II Laminair Flow (Biolaf, Ankara) $[28,29]$.

The L 1210 leukemia cell suspension was centrifuged at $2000 \mathrm{rpm}$ for 5 minutes. Cells were counted using the hemocytometer and the number of cells was adjusted to $1 \times 10^{5} / \mathrm{ml}$ cells for L 1210 cell assays. Preliminary experiments were done to determine the doses and bottomup method was used. $1 \mathrm{ml}$ of cell suspension was transferred to the test tubes and the test agents were added at concentrations of 15,30 , $60 \mu \mathrm{M}$. Same amount of serum physiological was added to the negative control tubes and same amount of DMSO was added to the Vehicle tubes, , and the tubes were placed in the incubator. The amount of DMSO in cell suspensions was not more than $1 \%$. After 24 hours, the tubes were removed from the incubator and the cell suspension was counted in 100 cell hemocytometer randomly selected at 1: 1 ( $\mathrm{v} / \mathrm{v})$ with $0.4 \%$ tryphan blue. Cell viability was expressed as a percentage. The same procedure was repeated after 48 hours and the experiment was terminated [30].

\subsection{Investigation of antibacterial properties}

The standard broth dilution method was used to measure the Minimum Inhibition Concentration (MIC) values of the in vitro antibacterial activities of the test compounds (3a-e).

To examine the antibacterial activities, the synthesized compounds (3a-e) and the control group were dissolved in DMSO (dimethylsulfoxide). Furthermore, dilution series in the order of decreasing concentrations of 1024, 512, 256, 128, 64, 32, 16, 8, $4 \mathrm{\mu g} \mathrm{ml}^{-1}$ were prepared for the microorganisms in the studiedsubject concentrations. Stock solutions were prepared in DMSO and DMSO was found to have no effect on the microorganisms in the concentration. The antibacterial activities of the compounds were determined according to the broth dilution method prescribed by the Clinical Laboratory Standards Committee (CLSI) [31].

The microorganisms used were two grams of positive and two grams of negative bacteria. $B$. subtilis ATCC 6633, S. aureus ATCC 6538 P strains were used as Gram positive bacteria and E. coli, ATTC 25922 and S. typhimurium NRRL B 4420 strains were used as Gram negative bacteria. As a standard antibiotic, Ampilisin was used for bacterial strains. 
Each bacterial strain, stained overnight, was seeded in nutrient broth ( $\mathrm{pH}$ 7.4) liquid medium under sterile conditions and allowed to incubate for 24 hours at $37^{\circ} \mathrm{C}$. Thus, the concentration of bacterial strains on the media was adjusted to $10^{5} \mathrm{CFU} \mathrm{ml-}{ }^{1}$.

Test compounds dissolved in DMSO were first prepared at a concentration of $1024 \mu \mathrm{g} \mathrm{ml}^{-1}$ and a series of dilutions were prepared at concentrations decreasing to as low as $4 \mu \mathrm{g} \mathrm{ml}{ }^{-}$ ${ }^{1}$ by adding the medium. Beside this, a series of control groups were prepared. The prepared dilution tubes were inoculated with the previously prepared bacterial cultures and allowed to incubate for 24 hours at $37^{\circ} \mathrm{C}$. Minimal Inhibition Concentration (MIC) values were calculated by post incubation turbidity assay method. Experiments were performed in two parallel runs.

\subsection{Statistics}

All statistical analyzes in this study were done with SPSS statistical program. Data obtained at the end of experimental studies, one-way
ANOVA Tukey test for antitumor activity was used

\section{RESULTS and DISCUSSION}

Obtained findings were tabulated for each of the parameters to show the comparisons of the groups to the control group throughout the trialn. Duration and dose-dependent cell viability results of the $\mathrm{L} 1210$ cells treated with the compound are shown in Table 2 ( 24 hour) and Table 3 ( 48 hour) the Minimum Inhibition Concentration values showing the antimicrobial activities of the test compounds are shown in Table 4.

In this study, it was found that duration and dose-dependent antitumor activity of compounds containing thiophene groups in vitro administered to the $\mathrm{L} 1210$ cell had different effects compared with the control group.

Table 2 shows that all of the substances used in the study had similar levels of antitumor activity, which is effective in the cell type L 1210.

Table 2. The in vitro antitumor activity of the test compounds (24 hours).

\begin{tabular}{lccc}
\hline Group n=6 & $\mathbf{1 5} \boldsymbol{\mu} \mathbf{M}$ & $\mathbf{3 0} \boldsymbol{\mu} \mathbf{M}$ & $\mathbf{6 0} \boldsymbol{\mu M}$ \\
\hline Control & $72.22 \pm 1,63$ & $66.00 \pm 1,28$ & $62.55 \pm 1,14$ \\
3a & $63.75 \pm 1,70^{\mathrm{a}}$ & $54.25 \pm 1,50^{\mathrm{a}}$ & $48,00 \pm 1,60^{\mathrm{a}}$ \\
3b & $66.25 \pm 1.75^{\mathrm{a}}$ & $50.00 \pm 0.99^{\mathrm{a}}$ & $40.25 \pm 1.44^{\mathrm{a}}$ \\
3c & $36.25 \pm 1.17^{\mathrm{b}}$ & $28.00 \pm 0.99^{\mathrm{b}}$ & $26.25 \pm 0.60^{\mathrm{b}}$ \\
3d & $44.55 \pm 1.80^{\mathrm{a}}$ & $30.50 \pm 1.19^{\mathrm{b}}$ & $26.00 \pm 0.20^{\mathrm{b}}$ \\
3e & $43.50 \pm 1.05^{\mathrm{a}}$ & $32.25 \pm 0.49^{\mathrm{b}}$ & $30.00 \pm 1.08^{\mathrm{b}}$ \\
\hline \multicolumn{4}{l}{ Data are presented as mean and standard error, a: $\mathrm{P}<0.001$ b: $\mathrm{P}<0.05$} \\
\hline
\end{tabular}

Table 3. The in vitro antitumor activity of the test compounds (48 hours).

\begin{tabular}{lccc}
\hline Group n=6 & $\mathbf{1 5} \boldsymbol{\mu M}$ & $\mathbf{3 0} \boldsymbol{\mu M}$ & $\mathbf{6 0} \boldsymbol{\mu} \mathbf{M}$ \\
\hline Control & $62.50 \pm 1.63$ & $58.50 \pm 0.78$ & $55.00 \pm 0.60$ \\
3a & $30.26 \pm 0.8^{\mathrm{a}}$ & $22.00 \pm 0.4^{\mathrm{b}}$ & $18.75 \pm 0.99^{\mathrm{b}}$ \\
3b & $32.25 \pm 1.44^{\mathrm{a}}$ & $28.75 \pm 1.05^{\mathrm{a}}$ & $20.50 \pm 0.63^{\mathrm{b}}$ \\
$\mathbf{3 c}$ & $20.25 \pm 1.53^{\mathrm{b}}$ & $18.75 \pm 0.71^{\mathrm{b}}$ & $11.22 \pm 0.22^{\mathrm{b}}$ \\
3d & $24.33 \pm 1.02^{\mathrm{a}}$ & $20.75 \pm 1.10^{\mathrm{b}}$ & $15.15 \pm 0.80^{\mathrm{b}}$ \\
3e & $25.00 \pm 1.49^{\mathrm{a}}$ & $20.25 \pm 0.33^{\mathrm{b}}$ & $16.75 \pm 0.95^{\mathrm{b}}$ \\
\hline \multicolumn{4}{l}{} \\
\hline \multicolumn{4}{l}{} \\
\hline
\end{tabular}

Studies investigating the anticancer and antitumor effects of thiophene compounds are rapidly increasing. Süleymanoğlu et al. have synthesized and characterized some new 
thiophene compounds and examined their antitumor properties. The compounds they synthesized showed high antitumor activity against some tumor cell types [32]. Diana et al. synthesized indole thiophene derivatives and examined their antitumor properties against a variety of tumor cells. These compounds were reported to be more active against some types of cancer [33]. Stolic et al. synthesized thiophene-based bis-benzimidazole amidines and examined their interaction with DNA and RNA. Some of these compounds have also been shown to exhibit high antitumor and antiparasitic activity at the same time [21]. Jiao et al. synthesized thiophene derivatives of phenyl propan amido benzamide and examined their antiproliferative activity on several human cancer cells. The compounds were observed to exhibit high activity. In addition, they have shown that these compounds have an effect in reducing the G2 phase in the cell cycle [20]. Romagnoli et al. have studied the biological properties of thiophenes by preparing chalcone and 2 and 3 amino benzo [b] thiophene derivatives. All of the compounds inhibited the development of cancer cells at micromolar concentrations [22, 18]. In our study, statistically significant differences were observed between the control group and other groups when the values of the substances at 15 , 30 and $60 \mu \mathrm{M}$ concentrations were examined at 24 and 48 hours. When the values of the substances of different concentrations are examined at 24 hours between the control group and the other groups, it can be said that the test substances $3 \mathrm{a}$ and $3 \mathrm{~b}$ have good activity close to the control value. However the other compounds (3c-e) showed moderate activity on both 24 hours and 48 hours.

Considering the results, it can be said that compounds containing thiophene groups possess antitumor activity. These results are in agreement with the findings in literature which reveal that the thiophene compounds are effective on antitumor activity.

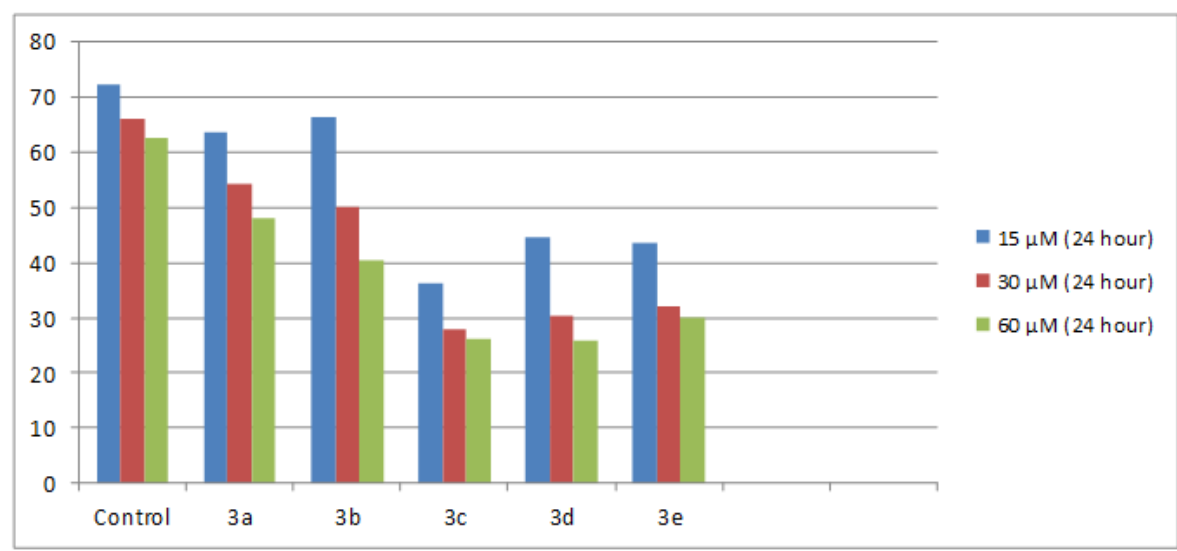

Figure 2. Comparison of antitumor activity of test compounds at the different concentrations $(50-100-250 \mu \mathrm{g} / \mathrm{mL})$ at $24 \mathrm{hour}$. 


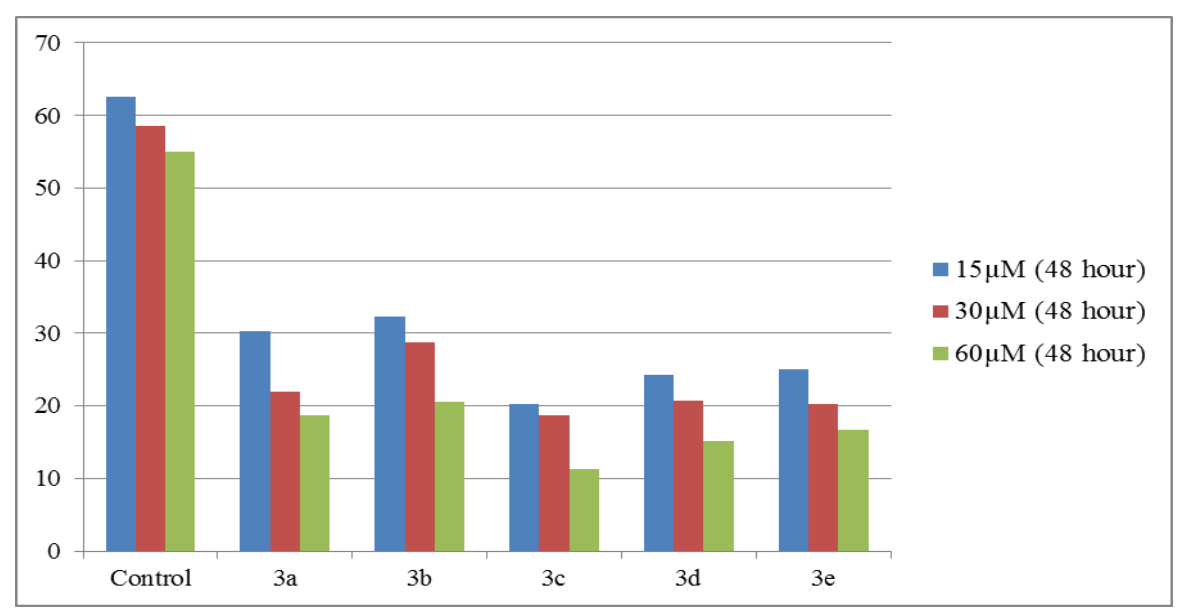

Figure 3. Comparison of antitumor activity of test compounds at the different concentrations $(50-100-250 \mu \mathrm{g} / \mathrm{mL})$ at $48 \mathrm{hour}$.

Pinto et al. have investigated the antifungal activities of heteroaryl amines by preparing benzo [b] thiophene derivatives. They found that the presence of hydroxyl group in aryl derivatives is necessary for antifungal activity. It was also observed that this effect was increased in pyridine derivatives [15]. In a study, benzo [b] thiophene compounds of ortho-chloro diaryl amines and heteroaromatic tetracyclic systems were synthesized and their antimicrobial properties werealso investigated [16].

Mohammed et al. have synthesized some metal complexes of the schiff base derived from 2thiophene carboxy aldehyde aminobenzoic acid and examined their antibacterial activity. They have found that metal complexes exhibit more effective activity than ligands [34].

In this study, the antimicrobial activities of the test compounds were studied according to the standard broth dilution method prescribed by the Clinical Laboratory Standards Committee (CLSI) [30]. The Minimum Inhibition Concentration (MIC) values of the test compounds against the Gram-positive bacteria of $B$. subtilis ATCC 6633, S. aureus ATCC $6538 \mathrm{P}$ strains and Gram negative bacteria of $E$. coli, ATTC 25922 and S. typhimurium NRRL B 4420 strains were calculated and the values were given in Table 4.

Table 4. The minimum inhibition concentration values $\left(\mu \mathrm{g} \mathrm{ml}^{-1}\right)$ of test compounds.

\begin{tabular}{lllll}
\hline Test Compounds & E.coli & B.subtilis & S.typhimurium & S.Aureus \\
\hline 3a & 64 & 64 & 64 & 1024 \\
3b & 64 & 64 & 64 & 512 \\
3c & 128 & 128 & 128 & 256 \\
3d & 256 & 256 & 256 & 1024 \\
3e & 256 & 256 & 256 & 256 \\
Ampicilin & 2 & 2 & 2 & 2 \\
\hline
\end{tabular}

It was observed that the antibacterial effects of the compounds varied between 64 and $1024 \mu \mathrm{g}$ $\mathrm{ml}^{-1}$. Among the test compounds, compound 3a and $3 \mathrm{~b}$ which has the highest antibacterial activity, has been shown to act against E.coli, $B$. subtilis and S. typhimurium strains at $64 \mu \mathrm{g} \mathrm{ml}$
1. According the results, the cyclohexyl and 3 'nitrophenyl groups we encoded in $3 \mathrm{a}$ and $3 \mathrm{~b}$ were found to have higher antitumor and antimicrobial activity. It has been shown in the literature [35-38] that cyclohexyl and nitrophenyl groups in the structure of the 
compounds show an effective antitumor and antimicrobial effect. Other compounds (3c-e) have shown modarate effect on the microorganisms. These results show that the test compounds used in this study demonstrate antibacterial effects.

The results of this study indicate that the new Thiophene-2,5-Dicarboxylic Acid Bis-Aryl (Alkyl) Amide compounds have antitumor and antibacterial properties. We believe that the results obtained in this study will pave the way for further synthesis of different substituted derivatives of this material and investigation of different activities in future studies.

\section{ACKNOWLEDGEMENTS}

We thank Dr. Metin Koparir for the gift of test compounds.

\section{REFERENCES}

[1]. Kandepu N.M., Mannich bases of chalcones and cyclohexanones as candidate cytotoxic agents, Ottawa: University of

Saskatchewan, Thesis(Phd) (1999).

[2]. Palaska E., Antikanser ilaçlar, 2nd ed. Ankara: Hacettepe Üniversitesi Yayınları, (2004).

[3]. Durackova Z, Mendiola M.A., Sevilla M.T., Valent A., Bioelect. and Bioener., 48 (1999) 109-116.

[4]. Xia Y., Qu F., Wu Q. and Peng L., Synthesis of bitriazolyl compounds via huisgen reactions, Heterocycles, 65 (2005) 345-352.

[5]. Holla B.S., Poojary N., Rao B.S. and Shivananda M.K., New bis-amino mercaptotriazoles and bistriazolothiadiazoles as possible anticancer agents, European Journal of Chemistry, 10 (2002) 1-7.

[6]. Molvi K.I., Mansuri M., Sudarsanam V., Patel M.M., Andrabi S.M.A. and Haque N., Synthesis antyinflammatory, analgesic, and antioxidant activities of some tetrasubstitued thiophenes, Journal of Enzyme Inhibition and Medicinal Chemistry, 23 (2008) 829-838.

[7]. Lesyk R., Vladzimirska O., Holota S., Zaprutko L. and Gzella A., New 5substituted thiazolo[3,2-b](1,2,4)triazole-6-ones: Synthesis and antycancer evaluation, European Journal of Medicinal Chemistry, 42 (2007) 641-648.

[8]. Mullican M.D., Wilson M.W., Conner D.T., Kostlan C.R., Schrier D.J. and Dyer R. D., Desing of 5-(3,5-di-tertbutyl-4-hydroxyphenyl)-1,3,4oxadiazoles and 1,2,4-triazoles as Orally-Active, Nonuleerogenic Antiinflammatory agents, Journal of Medicinal Chemistry, 36 (1939) 10901099.

[9]. Khanfar M.A., Hill R.A., Kaddoumi A. and El Sayed K.A., Discovery of novel GSK-3 $\beta$,nhibitors with potent in vitro and in vivo activities and excellent brain permeability using combined ligand- and structure-based virtual screening, Journal of Medicinal Chemistry, 53 (2010) 8534-8545.

[10]. Kulandasamy R., Adhikari A.V. and Stables J.P., A new class of anticonvulsants possesing $6 \mathrm{~Hz}$ activity: 3,4-Dialkyloxy thiophene bishydrazones, European Journal of Medicinal Chemistry, 44 (2009) 43764384.

[11]. Blanco J.M., Caamano O., Fernandez F., Mera X.G., Hergueta A.R., Lopez C., Borgez J.E.R., Balzarini J., de Clercq E., Chem. Pharm. Bull, 47 (1999) 1314-1317.

[12]. Christophe S.G., Caubere C.K., Renard P., Pfeiffer B., Pierre A., Leonce S., Caubera P., Bioorganic and Med. Chem. Let, 10 (2000) 2589-91.

[13]. Campaigne E. In Comprehensive Heterocyclic Chemistry; Katritzky A.R., Rees C.W., Eds.; Pergamon Press: Oxford, (1984) Vol. 2, pp 863934. 
[14]. Ronald K.R., Jefery B.P., In ComprehensiveHeterocyclic Chemistry II;Katritzky A.R., Rees C.W., Scriven E. F. V., Eds.; Pergamon Press: Oxford, (1996) Vol. 2, pp 679-729.

[15]. Pinto E., Queiroz M.J.R.P., Vale-Silva L.A., Oliveira J.F., Begouin A., JeanneMarie Begouin JM., Kirsch G., Bioorganic \& Medicinal Chemistry, 16 (2008) 8172-8177.

[16]. Queiroz M.R.R., Ferreira I. C. F. R., Gaetano Y.D., Kirsch G., Calhelhab R.C., Estevinhob L. M., Bioorganic \& Medicinal Chemistry, 14 (2006) 68276831.

[17]. Romagnoli R., Baraldi P.G., Carrion M. D., Cara C. L., Cruz-Lopez O., Preti D., Tolomeo M., Grimaudo S., Cristina A.D., Zonta N., Balzarini J., Brancale A., Sarkar T., Hamel E., Bioorganic \& Medicinal Chemistry 16 (2008) 53675376.

[18]. Romagnoli R., Baraldi P.G., Carrion M. D., Cara C. L., Cruz-Lopez O., Preti D., Fruttarolo F., Pavani M.G., Tabrizi M.A., Tolomeo M., Grimaudo S., Cristina A. D., Balzarini J., Hadfield J. A., Brancale A., Hamel E., J. Med. Chem, 50 (2007) 2273-2277.

[19]. Radwan M.A.A., Shehab M.A., ElShenawy S. M., Monatsh Chem. 140 (2009) 445-450.

[20]. Jiao J., Fang H., Wang X., Guan P., Yuan Y., Xu W., European Journal of Medicinal Chemistry, 44 (2009) 44704476.

[21]. Stolic I., Miškovic K., Magdaleno A., Silber A. M., Piantanida I., Bajic M., Glavaš-Obrovac L., Bioorganic \& Medicinal Chemistry 17 (2009) 25442554.

[22]. Romagnoli R., Baraldi P. G., Carrion M. D., Cara C. L., Cruz-Lopez O., Iaconinoto M. A., Preti D., Shryock J.C., Moorman A.R., Vincenzi F., Varani K., Borea P. A., J. Med. Chem., 51 (2008)5875-5879.
[23]. Parai M.K., Panda G., Chaturvedi V., Manjub Y.K., Sinhab S., Bioorganic \& Medicinal Chemistry Letters, 18 (2008) 289-292.

[24]. Singh S., Athar F., Maurya M.R., Azam A., European Journal of Medicinal Chemistry, 41 (2006) 592-598.

[25]. Sharma S., Athar F., Maurya M.R., Azam A., European Journal of Medicinal Chemistry, 40 (2005) 14141419.

[26]. Garcia-Tojal J., Garcia-Orad A., Serra J. L., Pizarro J.L., Lezama L., Arriortua M.I., Rojo T., Inorg. J., Biochem, 75 (1999) 45-54.

[27]. Koparır M., Cansiz A., and Cetin A., Thiophene-2,5-dicarboxylic Acid Bisaryl(alkyl) Amides Heteroatom Chemistry (2005) 16-6.

[28]. Offing O.E., Martelli S. Antibacterial Activity of Metal Complexes of Benzil and Benzoin Thiosemicarbazones, IL Farmaco., 49 (1994) 513-518.

[29]. Ferrari B.M., Capacchi S., Pelosi G., Reffo G., Tarasconi P., Albertini R., Pinelli S., Lungni P., Synthesis, Structural Characterization and Biological Activity of Helicin Thiosemicarbazone Monohydrate and a Copper (II) Complex of Salicylaldehyde Thiosemicarbazone, Inorganica Chimica Acta, (1999) 286, 134-141.

[30]. Kumammoto T., Toyooka K., Nishida M., Kuwahara H., Yashimura Y., Kawada J., Kubota S., Effect of 2,4Dihydro-3H-1,2,4- Triazole-3 -Thiones and Thiosemicarbazones on lodide Uptake by The Mause Thyroid, The Relationship Between Their Structure and Antithyroid Activity., Chem. Pharm. Bull., 38 (1990) 2595-2596.

[31]. Clinical Laboratory Standarts Institute (CLSI) M100-S23; Vol. 33 No.1, january 2013.

[32]. Süleymanoğlu N., Ustabaşı R., Alpaslan Y.B., Ünver Y., Turan M., Sancak K., Synthesis, spectroscopic 
characterization, calculational studies and in vitro antitumoral activity of 4-(3(1H-imidazol-1-yl)propyl)-(thiophen-2ylmethyl)-1H-1,2,4-triazol-5(4H)-one., Journal of Molecular Structure 989 (2011) 101-108.

[33]. Diana P., Carbone A., Barraja P., Montalbano A., Martorana A., Dattolo G., Gia O., Viab L.D., Cirrincionea G., Synthesis and antitumor properties of 2,5-bis(3-indolyl)thiophenes:

Analogues of marine alkaloid nortopsentin., Bioorganic \& Medicinal Chemistry Letters 17 (2007) 23422346.

[34]. Mohamed G. G., Omar M. M., Hindy A. M. M., Spectrochimica Acta Part A, 62 (2005) 1140-1150.

[35]. Mashooq AB., Mohamed A.O., Ahmed MN., Mohamed MA., Hoong-Kun F. Synthesis and antitumor activity of 4cyclohexyl/aryl-5-(pyridin-4- yl)-2,4dihydro-3H-1,2,4-triazole-3-thione Med Chem Res., 24 (2014).

[36]. Babu YH., Vasu Govardhana RP., Suresh RC., Devendranath RC., Uma MDP. Synthesis and antimicrobial activity of novel 2-alkyl/arylcarbamato6-(1,1-dimethylethyl)-3-cyclohexyl3,4-dihydro-2H-1,3,2benzoxazaphosphorine-2-oxides, Journal of Heterocyclic Chemistry, (2009).

[37]. Munichandra Reddy S., Subba Rao D., Madhu K., Subramanyam Ch., Gnana Kumari P. \& Naga Raju C. 2(Benzo[d]thiazol-2-yl) phenyl-4nitrophenyl alkyl/aryl substituted phosphoramidates: Synthesis, characterization and antimicrobial activity evaluation Phosphorus, Sulfur, and Silicon and the Related Elements, 193 (2018).

[38]. Song P., Yao X., Zhong T., Zhang S., Guo Y., Ren W., Huang D., Duan XC., Yin YF., Zhang SS., Zhang $X$. The anti-tumor efficacy of 3-(2Nitrophenyl) propionic acid-paclitaxel (NPPA-PTX): a novel paclitaxel bioreductive prodrug Oncotarget., 26 (2016) 48467-48480. 